\title{
Macerals of Shengli Lignite in Inner Mongolia of China and Their Combustion Reactivity
}

\author{
Ying Yue Teng, ${ }^{1}$ Yu Zhe Liu,, ${ }^{1}$ Quan Sheng Liu, ${ }^{1}$ and Chang Qing Li ${ }^{2}$ \\ ${ }^{1}$ College of Chemical Engineering, Inner Mongolia University of Technology, Inner Mongolia Key Laboratory of Industrial Catalysis, \\ Huhhot, Inner Mongolia 010051, China \\ ${ }^{2}$ Management College, Inner Mongolia University of Technology, Huhhot, Inner Mongolia 010051, China
}

Correspondence should be addressed to Quan Sheng Liu; 154118407@qq.com

Received 21 March 2016; Accepted 23 May 2016

Academic Editor: Hakan Arslan

Copyright (C) 2016 Ying Yue Teng et al. This is an open access article distributed under the Creative Commons Attribution License, which permits unrestricted use, distribution, and reproduction in any medium, provided the original work is properly cited.

\begin{abstract}
The macerals, including fusinitic coal containing $72.20 \%$ inertinite and xyloid coal containing $91.43 \%$ huminite, were separated from Shengli lignite using an optical microscope, and their combustion reactivity was examined by thermogravimetric analysis. Several combustion parameters, including ignition and burnout indices, were analyzed, and the combustion kinetics of the samples were calculated by regression. Fusinitic coal presented a porous structure, while xyloid coal presented a compact structure. The specific surface area of fusinitic coal was 2.5 times larger than that of xyloid coal, and the light-off temperature of the former was higher than that of the latter. However, the overall combustion reactivity of fusinitic coal was better than that of xyloid coal. The combustion processes of fusinitic and xyloid coals can be accurately described by both the homogeneous model and the shrinking core model. The features of xyloid coal agree with the shrinking core model when its conversion rate is $10 \%-90 \%$. The activation energy of fusinitic coal during combustion can be divided into three phases, with the middle phase featuring the highest energy. The activation energy of xyloid coal is lower than that of fusinitic coal in the light-off phase, which may explain the low light-off temperature of this coal.
\end{abstract}

\section{Introduction}

The study of macerals in coal has a long history. Several scholars have focused on the composition and classification of macerals and their appropriate testing methods $[1,2]$, while others have investigated the chemical reactivity of macerals $[3,4]$. However, as these previous studies mainly focus on bitumite and anthracite, few studies have concentrated on the macerals of low-rank coal. As energy shortages continue to threaten industries worldwide, utilization of low-rank coal, especially lignite, has generated great interest, and research on the macerals of lignite and the reactivity of these macerals has gradually increased [5]. Scholars have recently begun to study the composition, structure, and reactivity of lignite macerals $[1,6]$, especially those with hydrocarbon-generating potential, to expand the application scope of low-rank coal in the industry $[5,7]$.

Lignite macerals in different regions and the reactivity of these macerals differ because of variations in coal quality
$[7,8]$. The Shengli coalfield of Inner Mongolia is the largest open-pit coal mine in Asia, and the lignite produced by this coalfield is typical of the lignite in China. Shengli lignite differs significantly from other coals in terms of maceral type and maceral reactivity because of the high mineral, volatile matter, and oxygen contents of this coal. Shengli lignite contains high moisture contents, relatively large amounts of inorganic macerals, and inertinite [8]. In contrast to other coals, Shengli lignite exhibits self-ignition, high activity, and high ash production, all of which inhibit coking. Macerals are the key factor influencing lignite reactivity. Therefore, understanding the influence of macerals on the reactivity of lignite, especially its combustion, is critical for developing novel applications of lignite.

Previous studies $[4,9]$ demonstrate that the reactivities of coals and macerals within the coal are correlated. However, findings among studies often present different results because of the structural and composition complexity of coal [10]. While research has mainly focused on the coking process 


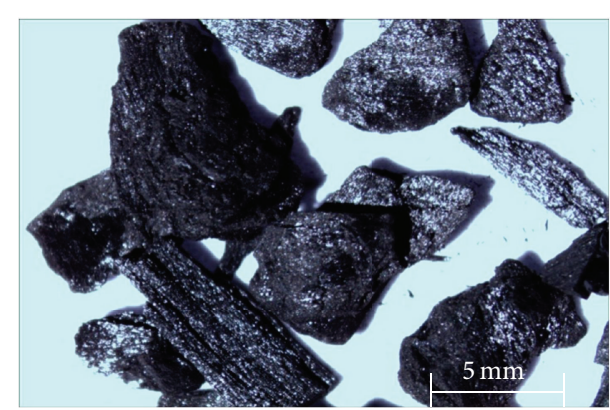

(a)

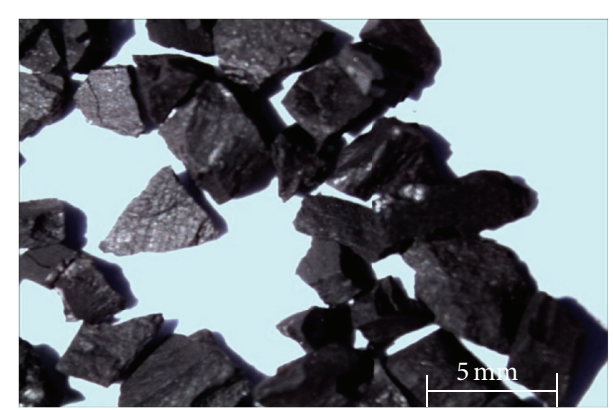

(b)

Figure 1: (a) Fusinitic coal $($ scale $=5 \mathrm{~mm})$ and (b) xyloid coal $($ scale $=5 \mathrm{~mm})$.

TABLE 1: Proximate and ultimate analyses of coal sample.

\begin{tabular}{|c|c|c|c|c|c|c|c|c|}
\hline \multicolumn{4}{|c|}{ Proximate analyses (\%) } & \multicolumn{5}{|c|}{ Ultimate analyses (\%) } \\
\hline $\mathrm{M}_{\mathrm{ad}}$ & $\mathrm{A}_{\mathrm{ad}}$ & $\mathrm{V}_{\text {daf }}$ & $\mathrm{F}_{\mathrm{Cad}}$ & $\mathrm{C}_{\mathrm{daf}}$ & $\mathrm{H}_{\mathrm{daf}}$ & $\mathrm{N}_{\mathrm{daf}}$ & $\mathrm{S}_{\mathrm{daf}}$ & $\mathrm{O}_{\mathrm{daf}}$ \\
\hline 8.24 & 9.94 & 32.26 & 52.20 & 76.63 & 3.85 & 0.98 & 2.39 & 16.15 \\
\hline
\end{tabular}

[11, 12], few studies describing macerals and the reactivity of lignite in China, especially lignite from Shengli, Inner Mongolia, are available, except for some investigations of the Ge distribution in Shengli coalfield [13, 14]. In this paper, we report new data on the structure of macerals of Shengli lignite as well as their corresponding combustion reactivity.

\section{Samples and Analytical Procedures}

2.1. Sample. Coal samples were collected from the face of number 6 coal bed in number 2 mine of Shengli coalfield, Inner Mongolia, China, according to the method of Dai et al. [14] following Chinese Standard Method GB/T 482-2008 (2008) [15]. All collected samples were immediately stored in plastic bags to minimize contamination and oxidation. The coal samples were crushed into $2-4 \mathrm{~mm}$ particles, sorted, and screened using an optical microscope. With the exception of the polished grain mount $(1 \mathrm{~mm})$, the samples to be analyzed were all crushed and ground to less than 200 meshes (SLR).

Proximate analysis was conducted following ASTM Standards [16-18]. An elemental analyzer (Vario MACRO, made in Germany, company of Elementar) was used to determine the percentages of $\mathrm{C}, \mathrm{H}, \mathrm{S}$, and $\mathrm{N}$ in the coal. Proximate and ultimate analyses of the coal samples were conducted in Inner Mongolia Key Laboratory of Industrial Catalysis. Samples were kept at the Inner Mongolia Key Laboratory of Industrial Catalysis and Petrology Laboratory in China University of Geosciences (Table 1).

2.2. Maceral Separation. Organic macerals of Shengli lignite were manually separated by a Nikon SMZ745T stereomicroscope and observed at magnifications of $3.55 \mathrm{x}-300 \mathrm{x}$ or up to $500 x$ using the appropriate imaging system.

Using an optical microscope, samples of different macerals were separated manually from $2-4 \mathrm{~mm}$ coal particles based on macro differences. In Figure 1(a), the coal is bright and presents a platy form and filamentous appearance; in
Figure 1(b), the coal is dark and hard in texture, without clear cavernous macerals on its surface. The images in Figures 1(a) and 1(b) present fusinitic coal (SLR-F) and xyloid coal (SLR$\mathrm{X}$ ), respectively [19]; this deduction will be further confirmed by coal petrography analysis.

2.3. Petrographic Analysis. The micro structures of the samples were analyzed using an S-3400N scanning electron microscope (Hitachi) in Inner Mongolia University of Technology under test conditions of $20 \mathrm{KV}$ accelerating voltage and backscattering electron imaging.

Maximum reflectance of vitrinite (percent Ro, max) (Table 2) was determined according to ASTM D2798-05 (2005) and ASTM D2797-04 (2005) [20, 21]. Coal petrography analysis was conducted in the petrology laboratory of China University of Geosciences. During resin addition, coal samples of $1 \mathrm{~mm}$ particle size were first shaped into coal briquettes, compacted, and then polished. Using an OPTONII reflected light microscope, the reflectivity of vitrinite was tested (observation conditions: oil immersion 40x, total magnification 500x).

2.4. Surface Area and Pore Structure Determination. The specific surface area was tested with a specific surface area and pore size analyzer via the static volumetric method. Samples of $0.3 \mathrm{~g}$ (200-400 meshes) were placed in a sample cell, vacuumed, and degassed at $105^{\circ} \mathrm{C}$ for $3 \mathrm{~h} . \mathrm{N}_{2}$ was then pumped into the cell, and the sample was weighed once more after cooling. A curve reflecting the adsorption and desorption processes of nitrogen was drawn, and the specific surface area, pore diameter, and volume of the samples were calculated using BET and BJH functions. The repeatability error was within $\pm 2 \%$.

Combustion reactivity was tested with a TG/DTA 6300 thermal analyzer under the following test conditions: sample weight of $10 \pm 0.1 \mathrm{mg}$, particle size of $38-75 \mu \mathrm{m}$ (200400 meshes), air atmosphere, gas flow rate of $100 \mathrm{~mL} / \mathrm{min}$, heating rate of $10^{\circ} \mathrm{C} / \mathrm{min}$, and temperatures ranging from indoor temperature to $950^{\circ} \mathrm{C}$.

\section{Results and Discussion}

3.1. Macerals. The lithotype of bituminous coal is a basic unit of coal distinguishable by the human eye. The International 
TABLE 2: Lithofacies analysis of SLR, SLR-X, and SLR-F.

\begin{tabular}{|c|c|c|c|c|c|c|c|}
\hline \multirow{3}{*}{ Sample } & \multirow{3}{*}{$R_{\mathrm{ran}}^{0}$} & \multirow{3}{*}{$\sigma_{n-1}$} & \multicolumn{5}{|c|}{ Maceral composition (\%) } \\
\hline & & & \multirow{2}{*}{ Huminite } & \multirow{2}{*}{ Iptinite } & \multirow{2}{*}{ Inertinite } & \multicolumn{2}{|c|}{ Mineral } \\
\hline & & & & & & Pyrite & Clay \\
\hline SLR & 0.21 & 0.037 & 48.18 & - & 34.02 & 0.21 & 18.05 \\
\hline SLR-F & 0.24 & 0.045 & 21.00 & 0.59 & 72.20 & - & 6.20 \\
\hline SLR-X & 0.27 & 0.052 & 91.43 & - & 7.78 & 0.34 & 0.44 \\
\hline
\end{tabular}

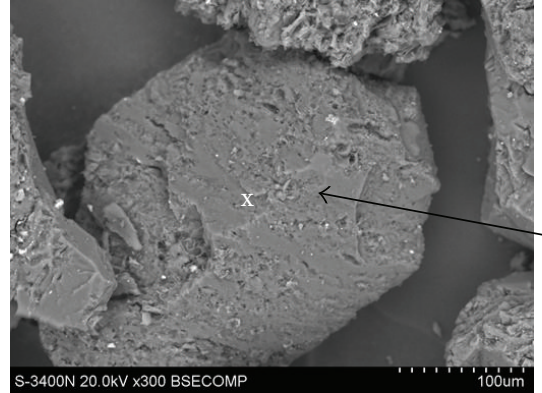

(a)

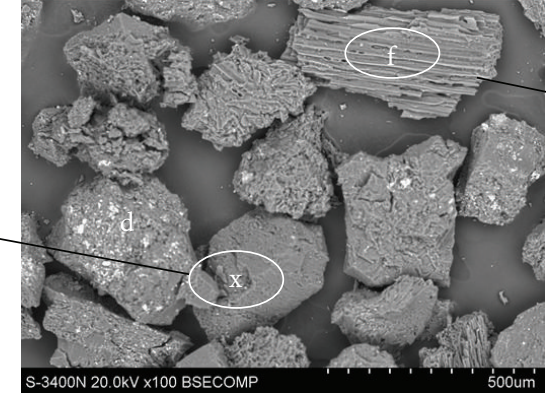

(b)

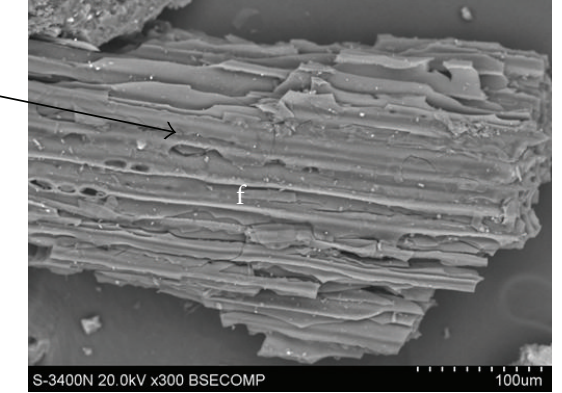

(c)

FIGURE 2: (a) SEM image of xyloid coal $(\mathrm{x})($ scale $=100 \mu \mathrm{m})$, (b) SEM image of detrital coal (d), xyloid coal (x), and fusinitic coal (f) $($ scale = $500 \mu \mathrm{m}$ ), and (c) SEM image of fusinitic coal (f) (scale $=100 \mu \mathrm{m})$.

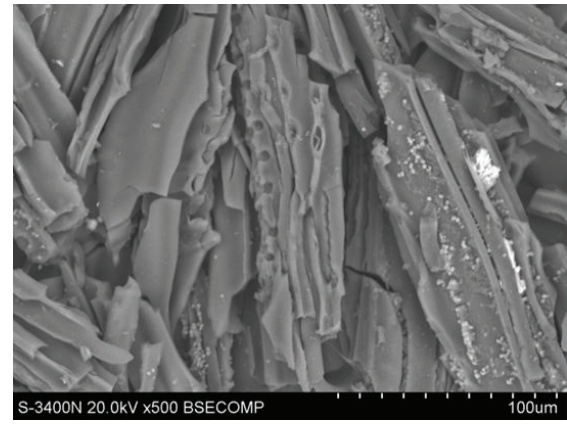

(a)

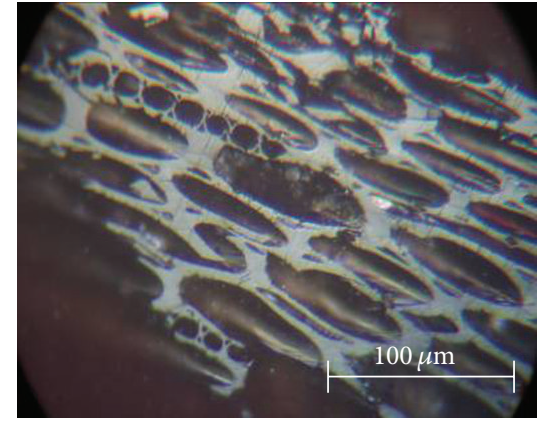

(b)

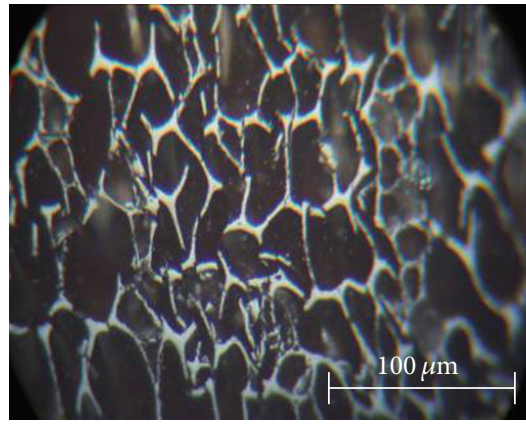

(c)

FIGURE 3: (a) SEM image of fusinitic coal (scale $=100 \mu \mathrm{m})$, (b) reflection microscopic image of a longitudinal section of fusinite $($ scale = $100 \mu \mathrm{m}$ ), and (c) reflection microscopic image of a transverse section of fusinite (scale $=100 \mu \mathrm{m}$ ).

Committee for Coal and Organic Petrology (ICCP) proposed a lithotype classification scheme for soft brown coal and identified four coal lithotypes based on their composition and compound structure: detrital coal, xyloid coal, fusinitic coal, and mineral-rich coal $[6,21]$; three of these lithotypes are easily identifiable in Shengli lignite (Figures 2(a)-2(c)).

Previous studies $[6,21]$ indicate that a tree structure represents fusinitic coal, compact coal represents xyloid coal, and compound structures represent detrital and mineral-rich coals. Under an optical microscope, the compound structure is difficult to identify, although fusinitic and xyloid coals differ in their morphology (e.g., fusinitic coal has a clear, stratified, and tubular structure). According to the SEM image of SLR (Figure 2(b)), lignite is basically composed of three microscopic structures, namely, a tree structure (Figures 2(b) and 2(c)), a compact structure (Figures 2(a) and 2(b)), and a compound structure.
Based on their features, fusinitic coal and xyloid coal were separated and designated as SLR-F and SLR-X, respectively. The corresponding SEM and reflective microscopy analysis results are shown in Figures 2 and 3.

The enrichment ratios of inertinite in SLR-F and huminite in SLR-X are 72.20 and 92.67, respectively; these component ratios are significantly higher than those in SLR (Table 2). In addition, lithofacies analyses confirm that SLR-F and SLR-X are fusinitic and xyloid coals, respectively $[6,21]$.

SEM and optical microscopy results show that fusinitic coal presents a clear, stratified, and tubular structure. This coal has a cellular cross section (Figures 2 and 3 ), large specific surface area, and minerals within its cavities (Figures 3(a) and 3(b)). Xyloid coal shows no clear porous microcomponents but has a hard texture, neat fractures (Figures 2 and 4), and levigelinite (Figure 4(b)) and undergoes cracking after dyeing (Figure 4(c)). 


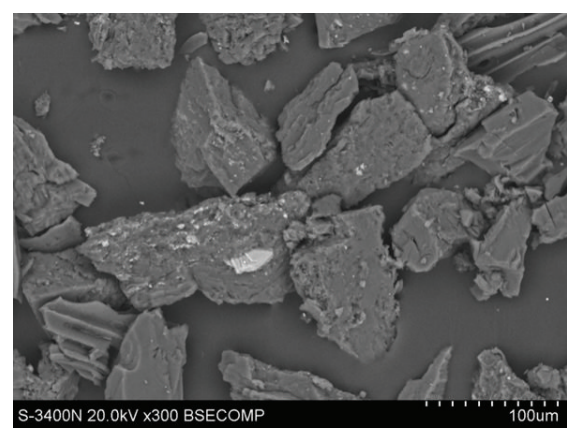

(a)

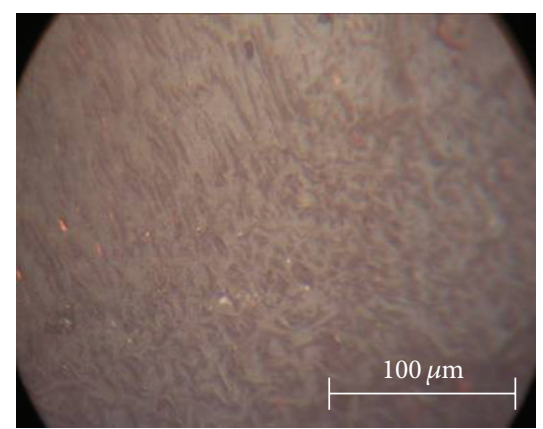

(b)

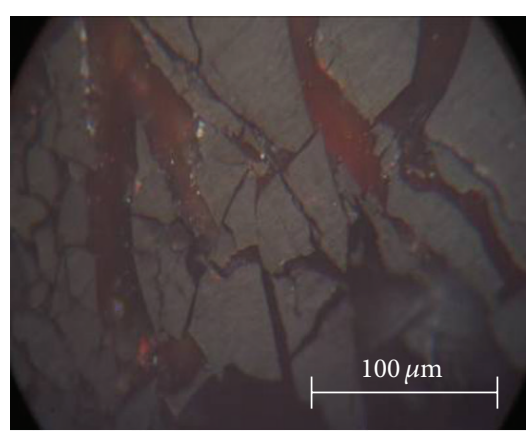

(c)

Figure 4: (a) SEM image of xyloid coal (scale $=100 \mu \mathrm{m}$ ), (b) reflection microscopic image of humotelinite $(\mathrm{scale}=100 \mu \mathrm{m})$, and $(\mathrm{c})$ reflection microscopic image of dehydrated fractures in humotelinite (scale $=100 \mu \mathrm{m})$.

TABLE 3: $\mathrm{N}_{2}$ cryogenic adsorption results of SLR-X and SLR-F.

\begin{tabular}{lcccc}
\hline Sample & Specific surface $\left(\mathrm{m}^{2} / \mathrm{g}\right)$ & Pore volume $(\mathrm{mL} / \mathrm{g})$ & Pore size $(\mathrm{nm})$ & Cumulative pore area $\left(\mathrm{m}^{2} / \mathrm{g}\right)$ \\
\hline SLR & 6.488 & 0.0352 & 40.6 & 9.99 \\
SLR-F & 12.48 & 0.0468 & 14.18 & 22.8 \\
SLR-X & 5.075 & 0.0778 & 89.28 & 7.96 \\
\hline
\end{tabular}

The specific surface areas of SLR, SLR-F, and SLR-X are $6.488,12.48$, and $5.075 \mathrm{~m}^{2} / \mathrm{g}$, respectively, which means fusinitic coal has a surface area 2.5 times larger than that of xyloid coal. The pore volume of fusinitic coal is $0.0468 \mathrm{~mL} / \mathrm{g}$, and its pore diameter is $14.18 \mathrm{~nm}$. By contrast, the pore volume of xyloid coal is $0.0778 \mathrm{~mL} / \mathrm{g}$, and its pore diameter is $89.28 \mathrm{~nm}$. Analysis results reveal that the micropores of fusinitic and xyloid coals are nearly equal but their larger pores vary greatly in size (Table 3 ).

3.2. Combustion Reactivity. The composition and structure of lignite determine its thermochemical reactivity $[1,12,22$, 23]. Because of the great differences in the morphologies and textures of SLR-F and SLR-X, the enrichment ratios of inertinite and huminite could be increased manually. The combustion reactivity of the coal samples in air was subsequently studied in this paper.

3.2.1. TG/DTG. The TG and DTG curves of SLR-F and SLR$\mathrm{X}$ during combustion are given in Figure 5. The combustion processes of SLR-F and SLR-X vary significantly. According to the DTG curves, in the combustion reactivity zone (above $\left.200^{\circ} \mathrm{C}\right)$, SLR-F shows two weight loss peaks at $\mathrm{F} 1\left(424^{\circ} \mathrm{C}\right)$ and $\mathrm{F} 2\left(533^{\circ} \mathrm{C}\right)$, whereas SLR-X shows three weight loss peaks at $\mathrm{X} 1\left(420^{\circ} \mathrm{C}\right), \mathrm{X} 2\left(463^{\circ} \mathrm{C}\right)$, and $\mathrm{X} 3\left(586^{\circ} \mathrm{C}\right)$. Comparison of the temperatures of the weight loss peaks of the coals and analysis of their TG and DTG curves reveal that xyloid coal presents better low temperature reactivity and easy ignition. However, above $415^{\circ} \mathrm{C}$, the oxidation rate of fusinitic coal is faster, its combustion performance is superior to that of xyloid coal, and it burns out earlier than xyloid coal. DTG curves show that the F1 peak is the highest among the peaks observed, which implies that the degree of volatile release at this point is the highest. By contrast, the three peaks of SLR-X are wide, which means this coal type may present 2-3 mild reactions.

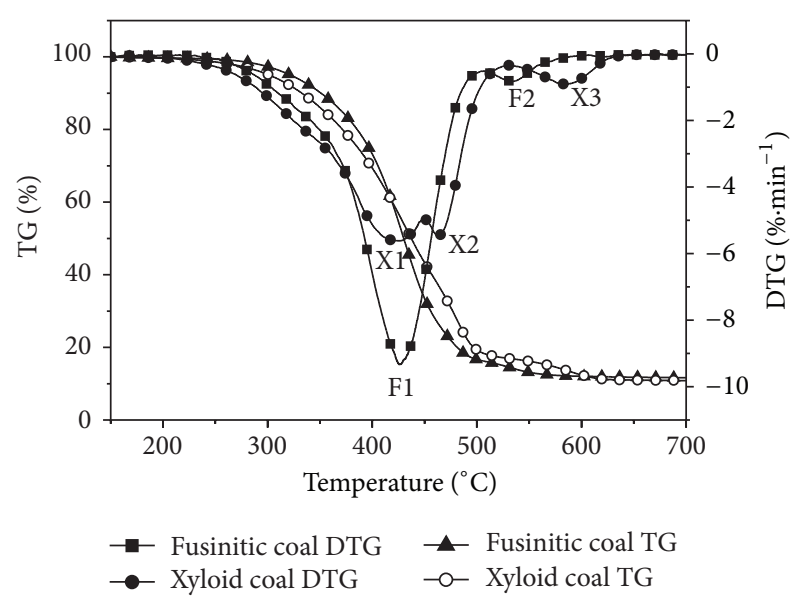

FIgURE 5: TG-DTG of SLR-X and SLR-F combustion.

F2 and X3 are probably caused by secondary combustion, that is, combustion of the char residue. The oxygen in the atmosphere first combines with the surface of the sample, thereby releasing a large amount of heat, which leads to increased surface temperatures and higher temperatures within the particles. At this point, combustion mainly occurs through the combination of oxygen and surface coal particles. Pyrolysis can only occur in the hot and oxygen-deficient environment within particles. Pyrolysis leads to a crosslinking reaction among molecular fragments and generates char residues of a larger molecular weight. As the carbon on the surface of the coal is consumed, the oxygen penetrates the char residue and combines with it. The second weight loss peak then appears. The weight loss peaks and weight loss rates vary among the different microscopic structures according to different reaction mechanisms. 
TABLE 4: Combustion characteristics of SLR-F and SLR-X.

\begin{tabular}{lcccccc}
\hline Sample & $\begin{array}{c}T_{i} \\
{ }^{\circ} \mathrm{C}\end{array}$ & $\begin{array}{c}(d w / d t)_{\max } \\
\% \cdot \min ^{-1}\end{array}$ & $\begin{array}{c}T_{\max } \\
{ }^{\circ} \mathrm{C}\end{array}$ & $\begin{array}{c}T_{f} \\
{ }^{\circ} \mathrm{C}\end{array}$ & $\begin{array}{c}D_{i} \\
\times 10^{-4}\end{array}$ & $\begin{array}{c}D_{f} \\
\times 10^{-5}\end{array}$ \\
\hline SLR-F & 373 & -9.38 & 424 & 503 & -67.6 & $\begin{array}{c}13.64 \\
\text { SLR-X }\end{array}$ \\
\hline
\end{tabular}

3.2.2. Combustion Parameters. The ignition temperature $T_{i}$ was determined based on TG/DTG method [24, 25]. The light-off index $D_{i}$ may be calculated using

$$
D_{i}=\frac{(d w / d t)_{\max }}{t_{p} t_{i}} .
$$

$D_{f}$, the burnout parameter, which can reflect the burnout characteristics of coal, may be calculated using

$$
D_{f}=\frac{(d w / d t)_{\max }}{\Delta t_{1 / 2} t_{p} t_{f}}
$$

where $(d w / d t)_{\max }$ is the maximum rate of weight loss $\left(\% \cdot \min ^{-1}\right), t_{p}$ is the time required to reach the maximum rate of weight loss ( $\mathrm{min}), t_{i}$ is the light-off time, $\Delta t_{1 / 2}$ is the time required to reach half of the maximum rate of weight loss (min), and $t_{f}$ is the burnout time.

The relevant parameters of combustion performance and calculation results are given in Table 4 . The light-off temperature of SLR-F is $373^{\circ} \mathrm{C}$, which is $13^{\circ} \mathrm{C}$ higher than that of SLR-X $\left(360^{\circ} \mathrm{C}\right)$. In the low temperature light-off phase, SLR-X is easier to light off than SLR-F; other combustion characteristics of SLR-F, however, are much better than those of SLR-X.

3.2.3. Kinetics. The combustion reactivity of coal involves a type of gas-solid reactivity that is very complicated because of the complex composition and structure of coal. Although many reactivity mechanisms, such as the oxygen exchange mechanism (oxygen absorption by the carbon surface to form carbon-oxygen compounds) [25], have been proposed and several kinetic models based on this mechanism have been put forward, many problems are still encountered during practical application. Therefore, the kinetic models commonly used in practice, such as the homogeneous model, the shrinking core model, the random pore model, the modified random pore model, and the modified volumetric model, are phenomenological models; of these, the homogeneous and unreacted shrinking core models are used most frequently. In the present paper, the homogeneous and unreacted shrinking core models were adopted to investigate the combustion reactivity of lignite microscopic structures [26].

According to the test results of TG/DTG, the combustion rate can be calculated using the following formula [26]:

$$
\frac{d x}{d t}=A \exp \left(-\frac{E}{R T}\right) f(x) .
$$

In this formula, $x$ represents the conversion rate:

$$
x=\frac{m_{0}-m}{m_{0}-m_{\infty}} \times 100 \%,
$$

where $m_{0}$ is the original weight of the sample, $m$ is the weight of the sample at any given time, and $m_{\infty}$ is the residual mass at the end of the reaction (all masses are in grams).

Simulations were performed under a controlled temperature. Hence, $T=T 0+\beta t$, where $\beta$ is a heating rate constant $(K \cdot S-1)$. And $K=A \exp (-E / R T)$.

Formulas (5) and (6) are obtained by $C-R$ integration [26]. For $n=1$ (homogeneous model),

$$
\ln \left[\frac{-\ln (1-x)}{T^{2}}\right]=\ln \left[\frac{A R}{\beta E}\right]-\frac{E}{R T} .
$$

For $n=2 / 3$ (shrinking core model),

$$
\ln \left[3 \frac{1-(1-x)^{1 / 3}}{T^{2}}\right]=\ln \left[\frac{A R}{\beta E}\right]-\frac{E}{R T} .
$$

The relationships between $\ln \left[-\ln (1-x) / T^{2}\right]$ and $1 / T$ and between $\ln \left[3\left(1-(1-x)^{1 / 3}\right) / T^{2}\right]$ and $1 / T$ are obtained using the homogeneous and shrinking core models. $E$ can be calculated according to the slope of the fitted straight line, and $A$ can be obtained using the linear intercept (Table 5). All of the relevant fitting coefficients are greater than 0.99 (Table 5), which means both models can accurately describe the combustion reactivity process of lignite microscopic structures and the rules of these models are basically similar. The combustion process of xyloid coal agrees with the shrinking core model when its conversion rate is $10 \%-90 \%$, which is wider than the fitting range of the homogeneous model. Therefore, the shrinking core model was adopted in this paper to analyze the combustion kinetic characteristics of lignite microscopic structures. Relevant kinetic parameters are listed in Table 5.

Under the reactivity testing conditions employed in this study, the combustion reactivity process of SLR-F can be divided into three reactivity zones, namely, the low temperature kinetic controlled area, the middle temperature kinetic controlled area, and the high temperature masstransfer control area. Before the conversion rate reaches $29.06 \%$ (temperatures below $400^{\circ} \mathrm{C}$ ), chemical reactivity is dominant and the activation energy is $63.23 \mathrm{~kJ} / \mathrm{mol}$. As temperature increases, the nature of reactivity changes, and the activation energy is $91.67 \mathrm{~kJ} / \mathrm{mol}$. Above $450^{\circ} \mathrm{C}$, the reactivity is mass-transfer controlled, and the activation energy is $41.40 \mathrm{~kJ} / \mathrm{mol}$. The combustion process of xyloid coal agrees with the shrinking core model when its conversion rate is $10 \%-90 \%$, and the activation energy of this coal is $50.26 \mathrm{~kJ} / \mathrm{mol}$.

Two types of combustion reactivity may be observed in the chemical reactivity-controlled zone of fusinitic coal. In the initial phase of reactivity, the activation energy is $63.23 \mathrm{~kJ} / \mathrm{mol}$, which is higher than the activation energy of xyloid coal $(50.26 \mathrm{~kJ} / \mathrm{mol})$. This finding implies that the combustion reactivity of fusinitic coal is poor in the light-off phase. At temperatures above $450^{\circ} \mathrm{C}$, the activation energy of fusinitic coal is $41.40 \mathrm{~kJ} / \mathrm{mol}$ whereas the activation energy of xyloid coal is $50.26 \mathrm{~kJ} / \mathrm{mol}$. The combustion performance of fusinitic coal is therefore superior to that of xyloid coal, which is consistent with the combustion characteristics of fusinitic 
TABLE 5: Kinetic parameters of coal.

\begin{tabular}{|c|c|c|c|c|c|c|}
\hline Model & Samples & Conversion (\%) & Temperature $\left({ }^{\circ} \mathrm{C}\right)$ & Activation energy $(\mathrm{kJ} / \mathrm{mol})$ & $A$ & $R^{2}$ \\
\hline \multirow{4}{*}{ Homogeneous model } & \multirow{2}{*}{ SLR-F } & $10.0-29.2$ & $345.8-398.5$ & 65.72 & 62.216 & 0.99907 \\
\hline & & $37.94-63.75$ & $410.9-437.4$ & 104.89 & $1.06 \times 10^{5}$ & 0.99987 \\
\hline & \multirow{2}{*}{ SLR-X } & $72.24-90$ & $446.5-480.6$ & 62.90 & 50.62 & 0.99675 \\
\hline & & $10.01-72.43$ & $327.4-467.4$ & 55.44 & 10.37 & 0.99924 \\
\hline \multirow{4}{*}{ Shrinking core model } & \multirow{2}{*}{ SLR-F } & $10-29.06$ & $345.62-398.27$ & 63.23 & 36.38 & 0.99939 \\
\hline & & $35.13-63.75$ & $407.34-437.39$ & 91.67 & 8458.27 & 0.99988 \\
\hline & \multirow{2}{*}{ SLR-X } & $74.63-90$ & $449.56-480.92$ & 41.40 & 0.87 & 0.99435 \\
\hline & & $10-90$ & $327.42-500.78$ & 50.26 & 3.404 & 0.99967 \\
\hline
\end{tabular}

coal shown in Table 3; here, a high light-off temperature and high light-off and burnout indices may be observed.

The activation energies of the two types of microscopic structures investigated in the present paper are basically similar to the activation energy of lignite $(20-100 \mathrm{~kJ} / \mathrm{mol})$ reported by other researchers [27].

\section{Conclusions}

The following conclusions may be drawn:

(1) Two microscopic structures, including fusinitic coal containing $72.20 \%$ inertinite and xyloid coal containing $91.43 \%$ huminite, were separated from Shengli lignite using an optical microscope. Fusinitic coal presents a clear, stratified, and tubular structure, cellular cross section, rich micropores, and a loose texture. Xyloid coal features a hard texture, small proportions of pores, and no clear porous microscopic constituents. The specific surface areas of fusinitic coal and xyloid coal are 12.48 and $5.075 \mathrm{~m}^{2} / \mathrm{g}$, respectively.

(2) Findings on ignition temperature $T_{i}$, light-off index $D_{i}$, and burnout index $D_{f}$ reveal that the light-off temperature of fusinitic coal is higher than that of xyloid coal. The comprehensive combustion reaction of the former, however, is better than that of the latter.

(3) Both the homogeneous and shrinking core models can accurately describe the combustion reactivity of SLF and SLX. The combustion process of xyloid coal agrees with the shrinking core model when its conversion rate is $10 \%-90 \%$. The activation energy of fusinitic coal can be divided into three phases, with the middle phase featuring the highest energy. The activation energy of xyloid coal is lower than that of fusinitic coal, which may explain the low light-off temperature of this coal type.

\section{Competing Interests}

The authors declare that they have no direct financial relation with the commercial identities mentioned in this paper that might lead to a conflict of interests for any of them.

\section{Acknowledgments}

This research was supported in part by the National Science Foundation of China (nos. 21566029, 71262022, and 21266017).

\section{References}

[1] A. M. George and G. H. Mackay, "Petrology," in The Science of Victorian Brown Coal: Structure, Properties and Consequences for Utilization, R. A. Durie, Ed., chapter 2, pp. 45-102, Butterworth-Heinemann, Oxford, UK, 1991.

[2] M. Mastalerz and R. M. Bustin, "Application of reflectance micro-Fourier Transform infrared analysis to the study of coal macerals: an example from the Late Jurassic to Early Cretaceous coals of the Mist Mountain Formation, British Columbia, Canada," International Journal of Coal Geology, vol. 32, no. 1-4, pp. 55-67, 1996.

[3] B. N. Nandi, T. D. Brown, and G. K. Lee, "Inert coal macerals in combustion," Fuel, vol. 56, no. 2, pp. 125-130, 1977.

[4] L. B. Méndez, A. G. Borrego, M. R. Martinez-Tarazona, and R. Menéndez, "Influence of petrographic and mineral matter composition of coal particles on their combustion reactivity," Fuel, vol. 82, no. 15-17, pp. 1875-1882, 2003.

[5] M. Havelcová, I. Sýkorová, H. Trejtnarová, and A. Šulc, "Identification of organic matter in lignite samples from basins in the Czech Republic: geochemical and petrographic properties in relation to lithotype," Fuel, vol. 99, pp. 129-142, 2012.

[6] I. Sýkorová, W. Pickel, K. Christanis, M. Wolf, G. H. Taylor, and D. Flores, "Classification of huminite-ICCP System 1994," International Journal of Coal Geology, vol. 62, no. 1-2, pp. 85-106, 2005.

[7] L. V. Shulyakovskaya, "Quantitative characteristics of hydrogenation reactivity of macerals of lignite from Kansk-Achinskoe field," Fuel and Energy Abstracts, vol. 38, no. 1, p. 5, 1997.

[8] P. Chen and J. Ma, "Petrographic characteristics of Chinese coals and their application in coal utilization processes," Fuel, vol. 81, no. 11-12, pp. 1389-1395, 2002.

[9] E. Hampartsoumian, W. Nimmo, P. Rosenberg, E. Thomsen, and A. Williams, "Evaluation of the chemical properties of coals and their maceral group constituents in relation to combustion reactivity using multi-variate analyses," Fuel, vol. 77, no. 7, pp. 735-748, 1998.

[10] C.-Z. Li, Advances in the Science of Victorian Brown Coal, Elsevier Science, London, UK, 2004. 
[11] L. Zhang, W. Liu, and D. Men, "Preparation and coking properties of coal maceral concentrates," International Journal of Mining Science and Technology, vol. 24, no. 1, pp. 93-98, 2014.

[12] S. Luo, S. He, X. Li, J. Li, W. Bi, and C. Sun, "Combustion kinetics of the coke on deactivated dehydrogenation catalysts," Fuel Processing Technology, vol. 129, pp. 156-161, 2015.

[13] G. Du, X. Zhuang, X. Querol et al., "Ge distribution in the Wulantuga high-germanium coal deposit in the Shengli coalfield, Inner Mongolia, northeastern China," International Journal of Coal Geology, vol. 78, no. 1, pp. 16-26, 2009.

[14] S. Dai, X. Wang, V. V. Seredin et al., "Petrology, mineralogy, and geochemistry of the Ge-rich coal from the Wulantuga Ge ore deposit, Inner Mongolia, China: new data and genetic implications," International Journal of Coal Geology, vol. 90, pp. 72-79, 2012.

[15] GB/T, "Sampling of coal in seam," GB/T 482-2008, National Standard of P.R. China, 2008 (Chinese).

[16] ASTM D3173-03, "Test method for moisture in the analysis sample of coal and coke," in Annual Book of ASTM Standards, vol. 05.06 of Gaseous Fuels; Coal and Coke, 2005.

[17] ASTM, "Test method for ash in the analysis sample of coal and coke from coal," in Annual Book of ASTM Standards. Volume 05.06: Gaseous Fuels; Coal and Coke, ASTM D3174-04, ASTM International, 2005.

[18] ASTM, "Test method for volatile matter in the analysis sample of coal and coke," in Annual Book of ASTM Standards. Volume 05.06: Gaseous Fuels; Coal and Coke, ASTM D3175-02, ASTM International, 2005.

[19] International Committee for Coal and Organic Petrology (ICCP), "New inertinite classification (ICCP System 1994)," Fuel, vol. 80, no. 4, pp. 459-471, 2001.

[20] ASTM, "Test method for microscopical determination of the vitrinite reflectance of coal," in Annual Book of ASTM Standards. Volume 05.06: Gaseous Fuels; Coal and Coke, ASTM D2798-05, ASTM International, 2005.

[21] ASTM D2797-04, "Practice for preparing coal samples for microscopical analysis by reflected light," in Annual Book of ASTM Standards, vol. 05.06 of Gaseous Fuels; Coal and Coke, 2005.

[22] R. López, C. Fernández, J. Cara, O. Martínez, and M. E. Sánchez, "Differences between combustion and oxy-combustion of corn and corn-rape blend using thermogravimetric analysis," Fuel Processing Technology, vol. 128, no. 12, pp. 376-387, 2014.

[23] C. Branca and C. Di Blasi, "Thermogravimetric analysis of the combustion of dry distiller's grains with solubles (DDGS) and pyrolysis char under kinetic control," Fuel Processing Technology, vol. 129, pp. 67-74, 2015.

[24] A. W. Coats and J. P. Redfern, "Kinetic parameters from thermogravimetric data," Nature, vol. 201, no. 4, pp. 68-69, 1964.

[25] H.-L. Tay and C.-Z. Li, "Changes in char reactivity and structure during the gasification of a Victorian brown coal: comparison between gasification in $\mathrm{O}_{2}$ and $\mathrm{CO}_{2}$," Fuel Processing Technology, vol. 91, no. 8, pp. 800-804, 2010.

[26] A. K. Sadhukhan, P. Gupta, and R. K. Saha, "Modelling of combustion characteristics of high ash coal char particles at high pressure: shrinking reactive core model," Fuel, vol. 89, no. 1, pp. 162-169, 2010.

[27] S.-Y. Lin, Y. Suzuki, and H. Hatano, "Expressing nth order charoxygen reaction initial rate under elevated pressure," Journal of Chemical Engineering of Japan, vol. 33, no. 5, pp. 753-760, 2000. 

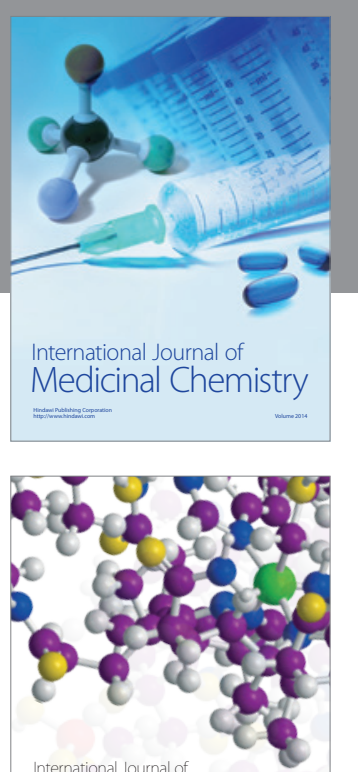

Carbohydrate Chemistry

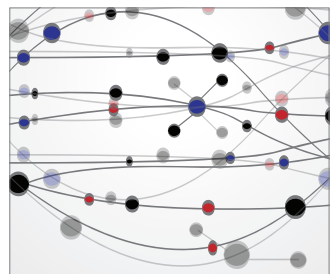

The Scientific World Journal
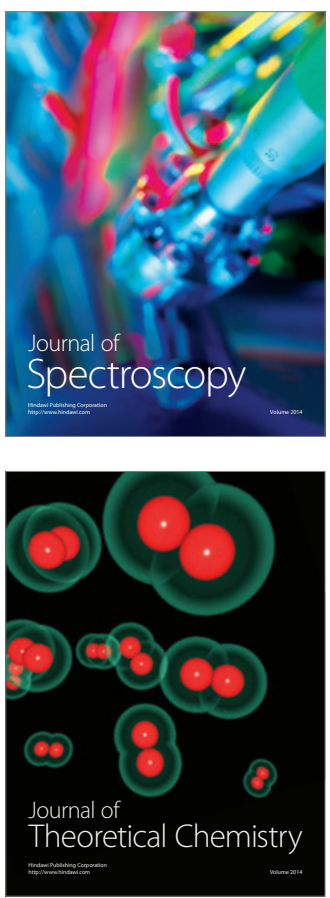
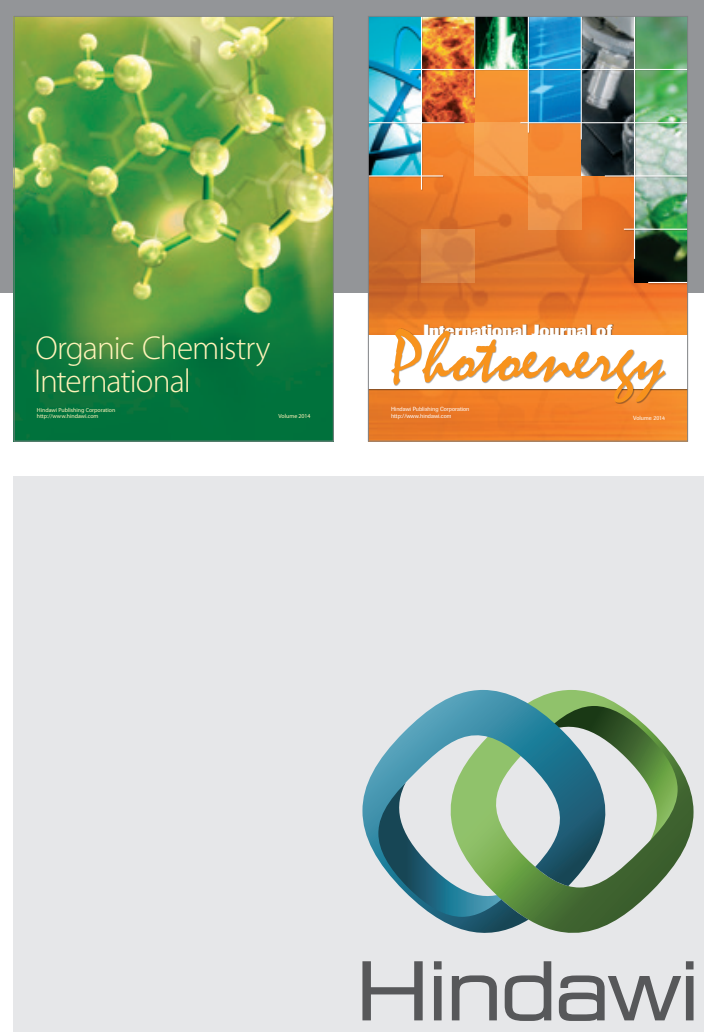

Submit your manuscripts at

http://www.hindawi.com

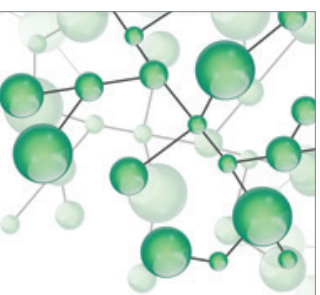

International Journal of

Inorganic Chemistry

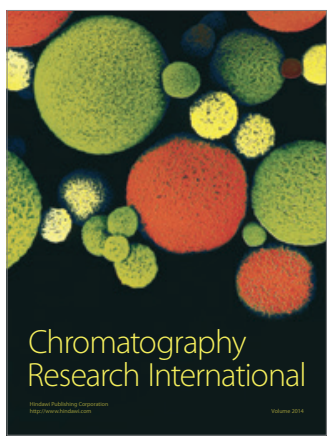

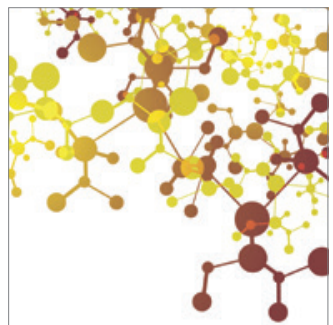

Applied Chemistry
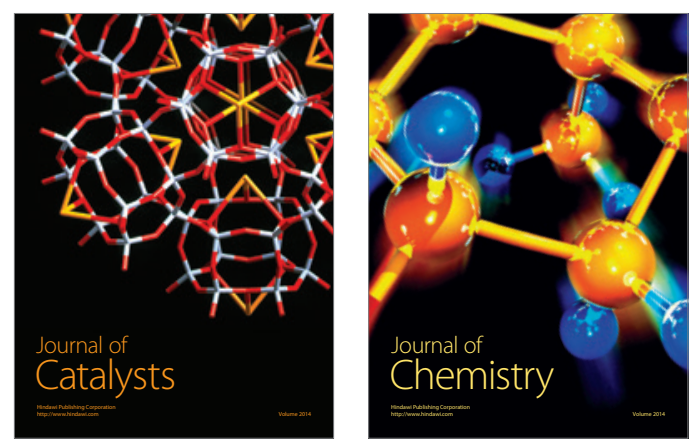
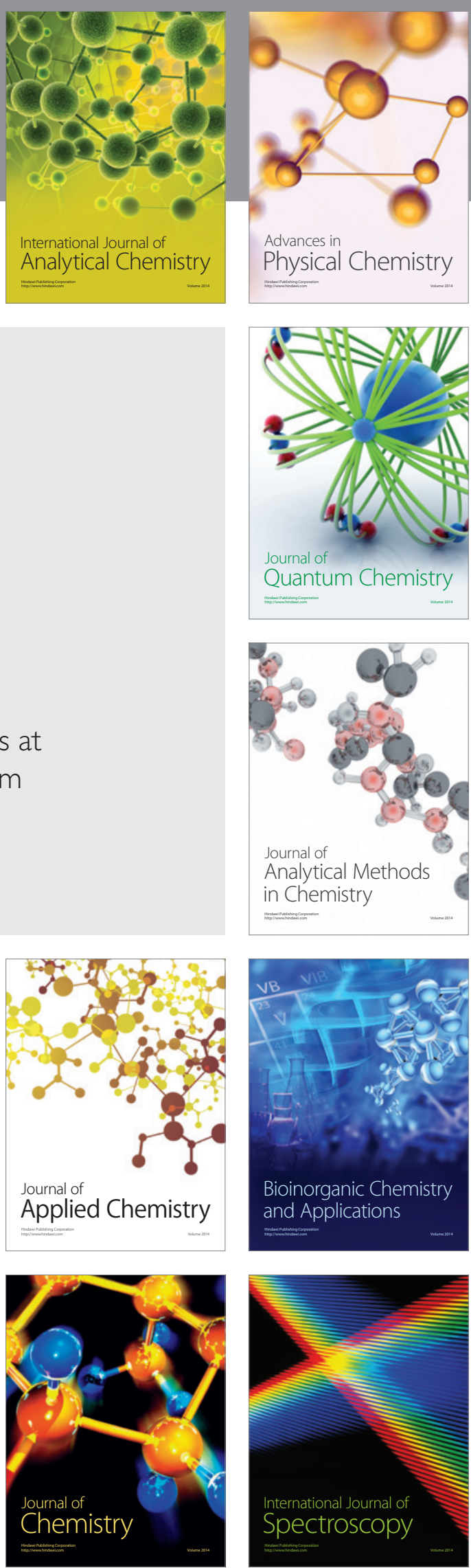